\title{
Pengembangan dan Validasi Kuesioner untuk Mengukur Penggunaan Internet dan Media Sosial dalam Pelayanan Kefarmasian
}

\author{
Catharina A. W. Heryanto, Claudia S. F. Korangbuku, Maria I. A. Djeen, Aris Widayati \\ Fakultas Farmasi, Universitas Sanata Dharma, Yogyakarta, Indonesia
}

\begin{abstract}
Abstrak
Saat ini dikenal pelayanan kesehatan berbasis teknologi informasi dan komunikasi (TIK) yang disebut dengan $e$-health dan pada pelayanan kefarmasian disebut e-pharmacy yang berkembang pesat. Namun demikian, penelitian mengenai persepsi apoteker tentang penggunaan internet untuk pelayanan kefarmasian di Indonesia masih sangat terbatas. Penggunaan kuesioner sebagai instrumen penelitian yang telah teruji validitas dan reliabilitasnya mutlak diperlukan. Oleh karena itu, penelitian ini bertujuan untuk mengembangkan dan menguji validitas dan reliabilitas kuesioner tentang persepsi penggunaan internet dan media sosial untuk pelayanan kefarmasian. Penelitian ini bersifat observasional deskriptif. Kuesioner yang diuji dinamakan Penggunaan Internet dan Media Sosial untuk Pelayanan Kefarmasian (PIMSAN). Uji validitas isi dilakukan dengan metode professional judgement dengan pendekatan kualitatif yaitu dengan professional agreement dan kuantitatif yaitu nilai items content validity index (I-CVI). Uji pemahaman bahasa dilakukan secara expert judgement dan uji coba kepada user yaitu tiga apoteker. Uji reliabilitas dilakukan dengan masing-masing 35 responden apoteker di apotek jejaring dan apotek nonjejaring dengan pendekatan nilai Chronbach Alpha. Hasil uji validitas isi putaran pertama menunjukkan belum ada kesepakatan antarpenguji (professional agreement) dengan nilai I-CVI sebesar 0,74. Professional agreement diperoleh pada putaran kedua dengan nilai I-CVI 0,98, sehingga kuesioner PIMSAN dinyatakan valid dengan 45 butir pertanyaan. Uji pemahaman bahasa oleh expert dinyatakan lolos uji dalam satu putaran saja. Uji pemahaman bahasa kepada user (apoteker) dinyatakan lolos uji setelah dua putaran. Pada uji reliabilitas, nilai Chronbach Alpha pada masing-masing apotek jejaring dan nonjejaring adalah 0,852. Berdasarkan hasil uji coba, kuesioner PIMSAN dinyatakan valid dan reliabel. Kuesioner PIMSAN dapat digunakan sebagai instrumen untuk mengukur persepsi apoteker tentang penggunaan internet dan media sosial untuk pelayanan kefarmasian di apotek.
\end{abstract}

Kata kunci: Internet, media sosial, pelayanan kefarmasian, uji kuesioner

\section{The Development and Validation of a Questionnaire to Study the Use of Internet and Social Media in Drug Information Service}

\begin{abstract}
The use of information and communication technology (ICT) in health sector which is called e-health, and e-pharmacy in pharmacy area, has become popular. However, research regarding the use of ICT in pharmaceutical care service especially from the pharmacists' views in the Indonesia context is still limited. Such research can be conducted using a validated questionnaire. Therefore, this study aimed to develop and test a questionnaire to measure pharmacists' perspective regarding the use of internet and social media for pharmaceutical care service. This is a descriptive study. The questionnaire is called PIMSAN, which stands for "Penggunaan Internet dan Media Sosial untuk Pelayanan Kefarmasian”. The validity test was conducted through a professional judgement method applied a qualitative approach using a professional agreement and a quantitative approach using items content validity index (I-CVI). The clarity of language in the items of the questionnaire was tested by expert judgement and to users, i.e. three pharmacists. The reliability of the questionnaire was measured by 35 pharmacists in individual pharmacies and 35 pharmacists in chain pharmacies. The Cronbach Alpha value was applied to determine the reliability of the questionnaire. Results of the first round of content validity test showed that a professional agreement had not yet been obtained and the I-CVI was 0.74. At the second round, a professional agreement had been achieved with I-CVI of 0.98, therefore the questionnaire was stated as valid with 45 questions. The clarity language testing with the expert was completed within one round only. The language tests with users (pharmacist) were completed within two rounds. The value of the Cronbach Alpha was 0.852 for both testing in individual and chain pharmacies. Based on the results, it can be stated that the PIMSAN questionnaire is valid and reliable. Therefore, the PIMSAN can be used as an instrument for a study examining pharmacists' perspective regarding the use of internet and social media for pharmaceutical care service in community pharmacies in Indonesia context.
\end{abstract}

Keywords: Internet, pharmaceutical care service, social media, questionnaire

Korespondensi: Aris Widayati, M.Si., Ph.D., Apt., Fakultas Farmasi, Universitas Sanata Dharma, Yogyakarta, Daerah Istimewa Yogyakarta 55281, Indonesia, email: ariswidayati31@gmail.com; ariswidayati@usd.ac.id Naskah diterima: 20 Juni 2019, Diterima untuk diterbitkan: 30 Agustus 2019, Diterbitkan: 28 September 2019 


\section{Pendahuluan}

Teknologi informasi dan komunikasi (TIK) telah berkembang pesat dalam beberapa tahun terakhir. Kemajuan TIK telah banyak berperan di dalam meningkatkan efisiensi serta memperluas akses layanan kesehatan. ${ }^{1}$ Pelayanan kesehatan saat ini sudah dimulai dengan menggunakan komputer berbasis TIK atau disebut sebagai $e$-health, sedangkan di bidang pelayanan kefarmasian berbasis TIK disebut e-pharmacy. ${ }^{2-4}$

Literasi e-health merupakan suatu keterampilan dalam memanfaatkan internet untuk mendapatkan informasi kesehatan. ${ }^{5}$ Baik di negara maju maupun berkembang, masyarakat telah memanfaatkan internet untuk mencari informasi kesehatan. Pada hasil survei penggunaan media komunikasi tahun 2013, diketahui bahwa 82,8\% masyarakat di Jepang dan 72\% masyarakat di Amerika Serikat (AS) menggunakan internet untuk mencari informasi kesehatan. ${ }^{6}$ Hasil survei di Indonesia menyebutkan bahwa sebanyak $51,06 \%$ masyarakat menggunakan internet untuk mencari informasi kesehatan dan sebanyak $14,05 \%$ masyarakat berkonsultasi dengan ahli kesehatan melalui internet. ${ }^{7}$ Sebuah studi di Yogyakarta menunjukkan bahwa sebanyak 52\% dan 99\% masyarakat mengakses internet setiap hari dan mencari informasi kesehatan di internet. ${ }^{8}$

Penelitian di beberapa negara menunjukkan TIK memiliki peran yang penting terhadap perkembangan pelayanan kefarmasian. Adanya apotek online mempermudah masyarakat dalam pemesanan obat. ${ }^{9-11}$ Di samping itu, internet dapat digunakan pula sebagai sarana penyediaan informasi dan pengembangan diri bagi seorang apoteker. ${ }^{12}$ Internet dan media sosial menyediakan berbagai informasi yang dibutuhkan seorang apoteker. Namun demikian, apoteker harus memiliki pemahaman dan keterampilan dalam memilah dan memilih informasi yang tersedia di internet. Media sosial juga dapat digunakan oleh apoteker untuk berkomunikasi dengan pasien maupun tenaga kesehatan lainnya. ${ }^{13}$

Penelitian yang mengkaji penggunaan internet untuk pelayanan kefarmasian dapat dilakukan dengan cara menggunakan angket atau kuesioner sebagai instrumen untuk mengumpulkan data. Penggunaan instrumen penelitian yang telah teruji validitas dan reliabilitasnya mutlak diperlukan dalam sebuah penelitian untuk menghasilkan data yang sahih dan handal. Beberapa penelitian terdahulu telah mengembangkan alat ukur yang berupa kuesioner untuk menginvestigasi pemanfaatan internet di bidang kesehatan, misalnya penelitian di negara Taiwan yang mengembangkan sebuah kuesioner mengenai penelusuran informasi melalui akses internet untuk pengambilan keputusan klinis ${ }^{14}$ dan penelitian di Inggris yang mengembangkan kuesioner untuk mengukur kesiapan pasien dalam memanfaatkan e-health. ${ }^{15}$ Namun demikian, penelitian dengan tema e-health, terutama e-pharmacy, di Indonesia masih sangat terbatas, sehingga belum banyak pula instrumen penelitian terkait topik tersebut yang telah teruji validitas dan reliabilitasnya dan dapat diterapkan dalam konteks Indonesia. Oleh karena itu, penelitian ini dilakukan dengan tujuan untuk mengembangkan dan menguji validitas dan reliabilitas instrumen penelitian berupa kuesioner yang dapat digunakan untuk mengukur persepsi apoteker tentang penggunaan internet dan media sosial untuk pelayanan kefarmasian di Indonesia, terutama di apotek. Di Indonesia, dikenal dua macam apotek berdasarkan kepemilikan dan pengelolaannya, yaitu apotek perseorangan/ individu (nonjejaring) dan apotek perseroan terbatas/waralaba (jejaring). ${ }^{16}$ Dalam hal pengelolaan dan sarana prasarana dari kedua jenis apotek tersebut, masing-masing memiliki karakteristik tersendiri. Hal tersebut kemungkinan berpengaruh pada karakteristik pelayanan kefarmasian yang berbasis pada 
internet (e-pharmacy). Oleh karena itu, pada penelitian ini, pengembangan kuesioner tentang penggunaan internet untuk pelayanan kefarmasian diujicobakan pada kedua jenis apotek tersebut, yaitu uji coba pada apotek perseorangan/individu (nonjejaring) dan perseroan terbatas/waralaba (jejaring).

\section{Metode}

Penelitian ini adalah penelitian yang bersifat observasional deskriptif dan dilakukan pada bulan Maret sampai Mei 2019. Izin penelitian telah diperoleh dari Badan Kesatuan Bangsa dan Politik (Kesbangpol) D.I. Yogyakarta dengan nomor 074/2052/Kesbangpol/2019, sedangkan ethical cleareance telah diperoleh dari Komisi Etik Penelitian Kedokteran dan Kesehatan Fakultas Kedokteran Universitas Kristen Duta Wacana nomor 945/C.16/FK/ 2019. Penelitian ini merupakan salah satu bagian dari penelitian besar yang bertema "Penggunaan Internet dan Media Sosial untuk Pelayanan Kefarmasian di Apotek-Apotek di D.I. Yogyakarta”.

\section{Pengembangan butir-butir pertanyaan pada kuesioner PIMSAN}

Instrumen penelitian yang dikembangkan berupa kuesioner dengan sebutan akronim PIMSAN, yang merupakan singkatan dari "Penggunaan Internet dan Media Sosial untuk Pelayanan Kefarmasian”. Penyusunan kuesioner PIMSAN mengacu pada penelitian Shcherbakova dan Shepherd di Texas, USA. ${ }^{13}$

Rancangan pertama kuesioner PIMSAN (Ver01) terdiri dari 6 bagian, yaitu:1) Bagian A yang berupa pertanyaan tentang karakteristik responden dan sarana prasarana teknologi informasi dan komunikasi (TIK) di apotek sebanyak 14 butir pertanyaan; 2) Bagian B yang berupa pertanyaan tentang penggunaan internet oleh apoteker sebagai suatu sarana komunikasi profesional sebanyak 4 butir pertanyaan; 3) Bagian $\mathrm{C}$ berupa pertanyaan tentang jenis aktivitas profesional apoteker yang dilakukan dengan berbantukan internet sebanyak 10 butir pertanyaan; 4) Bagian D berupa pertanyaan tentang persepsi apoteker mengenai penggunaan media sosial untuk berkomunikasi sebanyak 12 butir pertanyaan; 5) Bagian E berupa pertanyaan tentang hambatan terhadap pemanfaatan internet dan media sosial untuk berkomunikasi secara profesional sebanyak 2 butir pertanyaan; 6) Bagian $\mathrm{F}$ berupa pertanyaan tentang harapan terhadap pemanfaatan internet dan media sosial untuk berkomunikasi sebanyak 1 butir pertanyaan. Total jumlah butir pertanyaan pada rancangan pertama kuesioner PIMSAN (Ver01) sebanyak 43 buah.

\section{Uji validitas isi (content validity) kuesioner PIMSAN}

Uji validitas isi dilakukan terhadap semua bagian kuesioner PIMSAN (Ver01). Uji validitas isi bertujuan untuk memastikan bahwa seluruh pertanyaan di dalam kuesioner telah mencakup kawasan atau ruang lingkup yang akan diukur. ${ }^{17}$ Uji validitas isi dalam penelitian ini dilakukan secara professional judgement dengan pendekatan kualitatif dan kuantitatif. Terdapat dua apoteker yang dilibatkan sebagai validator untuk melakukan uji validitas isi kuesioner secara kualitatif, sedangkan untuk pendekatan kuantitatif, tiga orang apoteker dilibatkan sebagai tim panel validator. Pemilihan validator ini ditetapkan berdasarkan keahlian dan pengalamannya terkait cakupan isi kuesioner yang diuji, yaitu pelayanan kefarmasian di apotek.

Alat dan bahan uji validitas isi

Pada uji validitas isi, alat dan bahan yang digunakan yaitu rancangan kuesioner PIMSAN, Form 1 yaitu formulir penilaian kelayakan isi kuesioner, Form 2 yaitu pernyataan kelayakan validitas isi, serta pustaka yang digunakan sebagai acuan untuk pengembangan butir-butir pertanyaan kuesioner PIMSAN. ${ }^{13}$ 
Langkah-langkah uji validitas isi

Uji validitas isi pada penelitian ini dilakukan dengan urutan langkah-langkah berikut: 1) Menyerahkan rancangan kuesioner PIMSAN yang pertama (Ver01) kepada validator disertai dokumen Form 1, Form 2, dan pustaka acuan; 2) Menerima kembali Form 1 dan Form 2 yang telah diisi oleh validator; 3) Melakukan analisis terhadap hasil validasi dari validator yang tertuang di dalam Form 1 dan Form 2; 4) Berdasarkan hasil analisis terhadap hasil validasi pada Form 1 dan Form 2 tersebut, diputuskan apakah masih akan dilakukan validasi untuk putaran berikutnya (kedua, ketiga, dan seterusnya) sampai diperoleh hasil semua pertanyaan dalam kuesioner dinyatakan valid, yaitu ketika telah tercapai professional agreement di antara tim validator dan nilai items content validity index (I-CVI) $\geq 0,78 .^{17}$

Pada uji validitas isi dengan pendekatan kualitatif, pengolahan dan analisis data dilakukan dengan cara diskusi dan melakukan verifikasi antara tim peneliti dengan tim panelis/validator sehingga diperoleh suatu kesepakatan atau professional agreement terhadap butir-butir pertanyaan yang dinilai belum layak/valid. Pada uji validitas isi dengan pendekatan kuantitatif, pengolahan dan analisis data dilakukan dengan cara memberikan skor pada hasil penilaian tim panelis/validator. Pada tiap butir pertanyaan yang dinilai oleh validator, diberikan skor dikotomi yaitu 1 jika sesuai/layak dan 0 jika tidak sesuai/tidak layak. Dari hasil pemberian skor kemudian dilakukan penghitungan nilai rasio I-CVI. Apabila nilai I-CVI $\geq 0,78$, butir pertanyaan tersebut dinyatakan layak/valid. ${ }^{17}$

\section{Uji pemahaman bahasa kuesioner PIMSAN}

Uji pemahaman bahasa dilakukan terhadap seluruh bagian kuesioner PIMSAN yang telah dinyatakan valid dengan dua cara, yaitu secara expert judgement dan uji coba kepada user. Uji pemahaman bahasa kepada expert bertujuan untuk memastikan pilihan kata yang digunakan sesuai untuk mengungkapkan makna dari pertanyaan. Expert yang dipilih pada uji pemahaman bahasa ini yaitu apoteker yang paham penggunaan TIK untuk pelayanan kefarmasian. Uji coba kepada user bertujuan untuk memastikan bahasa yang digunakan dapat dipahami oleh responden pada saat mengisi kuesioner nanti. Uji pemahaman bahasa kepada user dilakukan kepada tiga orang apoteker yang berpraktik pelayanan kefarmasian di apotek.

Alat dan bahan uji pemahaman bahasa Alat dan bahan uji pemahaman bahasa yakni berupa kuesioner PIMSAN yang telah dinyatakan valid dan Form 3 yang berisi pernyataan mengenai pemahaman bahasa dari pertanyaan-pertanyaan pada kuesioner yang diuji coba.

Langkah-langkah uji pemahaman bahasa

Uji pemahaman bahasa dalam penelitian ini dilakukan dengan urutan langkah-langkah sebagai berikut: 1) Menyerahkan kuesioner PIMSAN yang sudah dinyatakan valid dan Form 3 kepada responden uji pemahaman bahasa; 2) Menerima kembali Form 3 yang telah diisi oleh responden uji; 3) Melakukan analisis terhadap data yang tertuang di dalam Form 3; 4) Berdasarkan hasil analisis data dari Form 3 tersebut, lalu diputuskan apakah akan dilanjutkan proses uji di putaran selanjutnya (putaran kedua, ketiga, dan seterusnya) sampai diperoleh hasil bahwa semua kata/bahasa yang digunakan dalam pertanyaan-pertanyaan pada kuesioner PIMSAN telah dipahami.

Pada uji pemahaman bahasa, expert dan user sekaligus diminta menilai kelayakan "muka" atau tampilan dan tata letak (layout) kuesioner yang lazimnya disebut uji validitas muka (face validity). Selain itu, mereka juga diminta menilai apakah penempatan urutan pertanyaan-pertanyaan kuesioner telah runtut dan alurnya mudah diikuti oleh responden. 


\section{Uji reliabilitas kuesioner PIMSAN}

Uji reliabilitas dilakukan pada bagian kuesioner PIMSAN yang berbentuk skala Likert, yaitu Bagian D yang berisi pertanyaan mengenai persepsi apoteker tentang penggunaan media sosial untuk pelayanan kefarmasian. Uji reliabilitas dilakukan dengan teknik konsistensi internal. Uji reliabilitas ini bertujuan untuk memastikan bahwa kuesioner PIMSAN dapat dipercaya dan diandalkan sebagai alat untuk pengambilan data penelitian. ${ }^{18}$

Bahan uji reliabilitas

Bahan uji reliabilitas yakni berupa kuesioner PIMSAN yang sudah dinyatakan valid dan lolos uji pemahaman bahasa.

Responden uji reliabilitas

Uji reliabilitas dilakukan kepada responden apoteker yang melakukan praktik pelayanan kefarmasian di dua kategori tempat praktik, yaitu apotek jejaring dan apotek nonjejaring (individu) di lima wilayah di Provinsi D.I. Yogyakarta, antara lain Kota Yogyakarta, Kabupaten Gunung Kidul, Kabupaten Kulon Progo, Kabupaten Bantul, dan Kabupaten Sleman. Responden apoteker yang dipilih adalah Apoteker Pengelola Apotek (APA). Jumlah responden uji di masing-masing kategori tempat praktik adalah 35 responden.

Pengambilan data uji reliabilitas

Pengambilan data dilakukan pada waktu dan tempat yang sudah disepakati dengan responden. Responden diberikan penjelasan singkat terkait tujuan penelitian dan diminta mengisi dan menandatangani informed consent terkait kesukarelaan berpartisipasi dalam penelitian ini. Pengisian kuesioner dilakukan oleh responden selama 20 sampai 30 menit.

Pengolahan data uji reliabilitas

Pengolahan data diawali dengan pemeriksaan terhadap kelengkapan data pada kuesioner yang telah diisi oleh responden. Pemberian skor pada tiap pertanyaan dilakukan sesuai dengan jenis pertanyaannya, yaitu favorable dan unfavorable. Skor untuk pertanyaan yang berjenis favorable adalah SS (sangat setuju $)=5 ; \mathrm{S}$ (setuju) $=4$; RR $($ ragu-ragu $)=3$; TS $($ tidak setuju) $=2$; dan STS ( sangat tidak setuju) $=1$, sedangkan skor untuk pertanyaan jenis unfavorable adalah STS (sangat tidak setuju) $=5$; TS $($ tidak setuju) $=4$; RR (raguragu) $=3 ; \quad S \quad$ (setuju) $=2$; dan SS (sangat setuju) $=1$. Data berupa skor tiap pertanyaan tersebut lalu dimasukkan dan disimpan dalam program Ms. Excel. Selanjutnya, data tersebut diolah dengan metode Cronbach Alpha yang tersedia di program IBM SPSS version 22 berlisensi. Nilai reliabilitas dinyatakan baik dengan nilai Cronbach Alpha berkisar antara 0,7 sampai $0,95 .{ }^{19}$ Rincian langkah-langkah proses validasi isi, uji pemahaman bahasa, uji validitas muka, dan uji reliabilitas butir-butir pertanyaan pada kuesioner PIMSAN dapat dilihat pada Gambar 1.

\section{Hasil}

\section{Hasil uji validitas isi kuesioner PIMSAN}

Pendekatan kualitatif

Pada putaran pertama uji validitas isi terdapat penambahan tiga butir pertanyaan, sehingga total jumlah pertanyaan menjadi 46 butir. Penambahan butir pertanyaan terjadi pada bagian B sebanyak dua butir yaitu tentang penggunaan Short Message Service (SMS) dan pada bagian D sebanyak satu pertanyaan terkait informasi hoaks kesehatan. Pada putaran pertama juga dilakukan perbaikanperbaikan pertanyaan berdasarkan pemilihan kata sesuai dengan saran dari validator. Pada putaran kedua, terdapat pengurangan satu butir pertanyaan pada bagian A terkait jenis jaringan internet (LAN, Wireless LAN, dan paket data). Pada uji putaran kedua diperoleh kesepakatan berupa professional agreement 


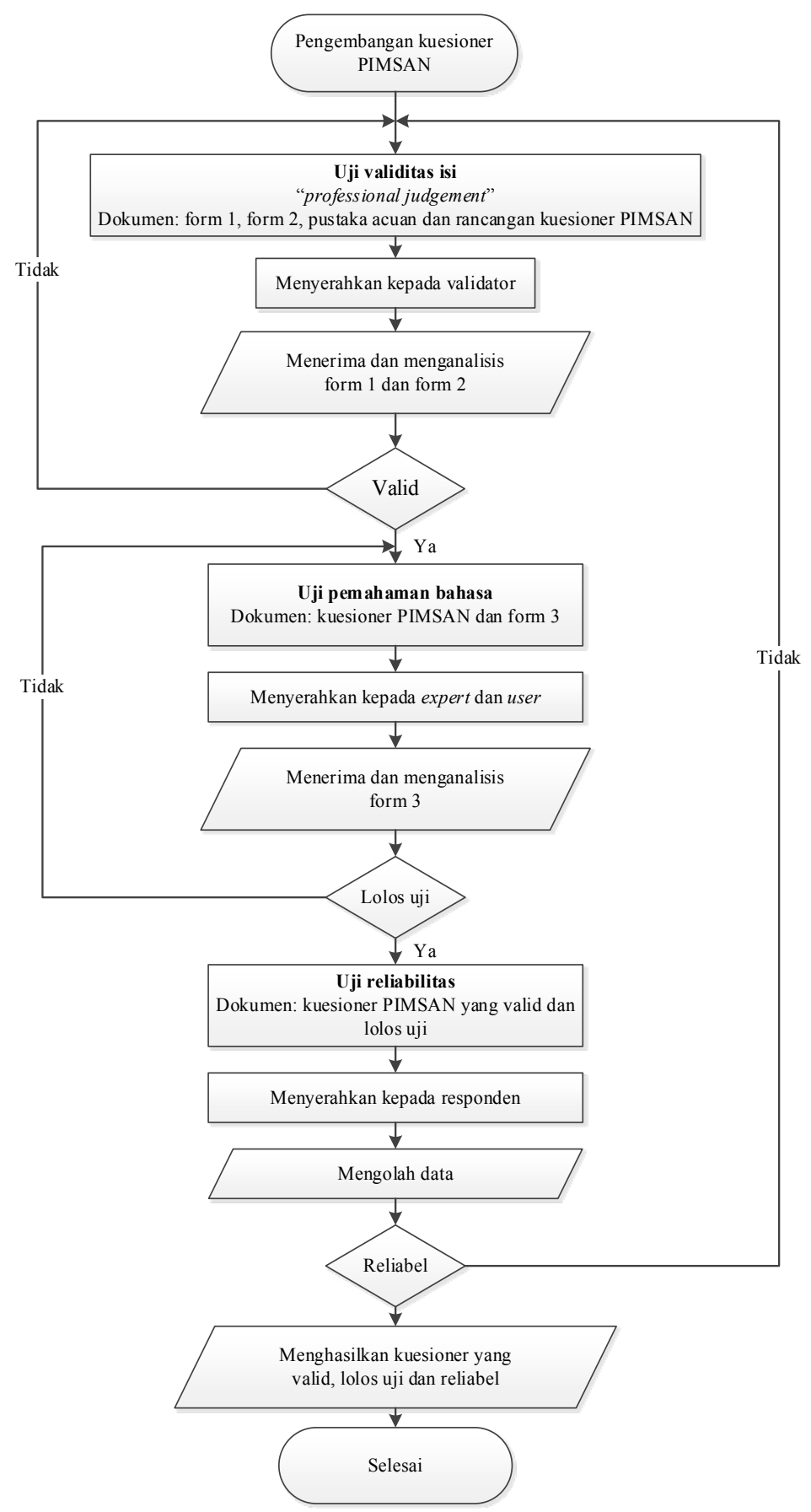

Gambar 1 Proses Validasi Isi, Uji Pemahaman Bahasa, dan Uji Reliabilitas Kuesioner "Penggunaan Internet dan Media Sosial untuk Pelayanan Kefarmasian (PIMSAN)"

dengan jumlah akhir butir pertanyaan sebanyak 45 butir yang dinyatakan valid.

\section{Pendekatan kuantitatif}

Berdasarkan Tabel 1, uji validitas isi pada putaran pertama terhadap 43 butir pertanyaan secara keseluruhan proporsi butir pertanyaan valid kuesioner PIMSAN yakni sebesar 65\%, $72 \%, 84 \%$ dari masing-masing validator (total terdapat 3 validator). Pada uji putaran kedua, diperoleh proporsi butir pertanyaan valid secara keseluruhan sebesar 98\% dari 


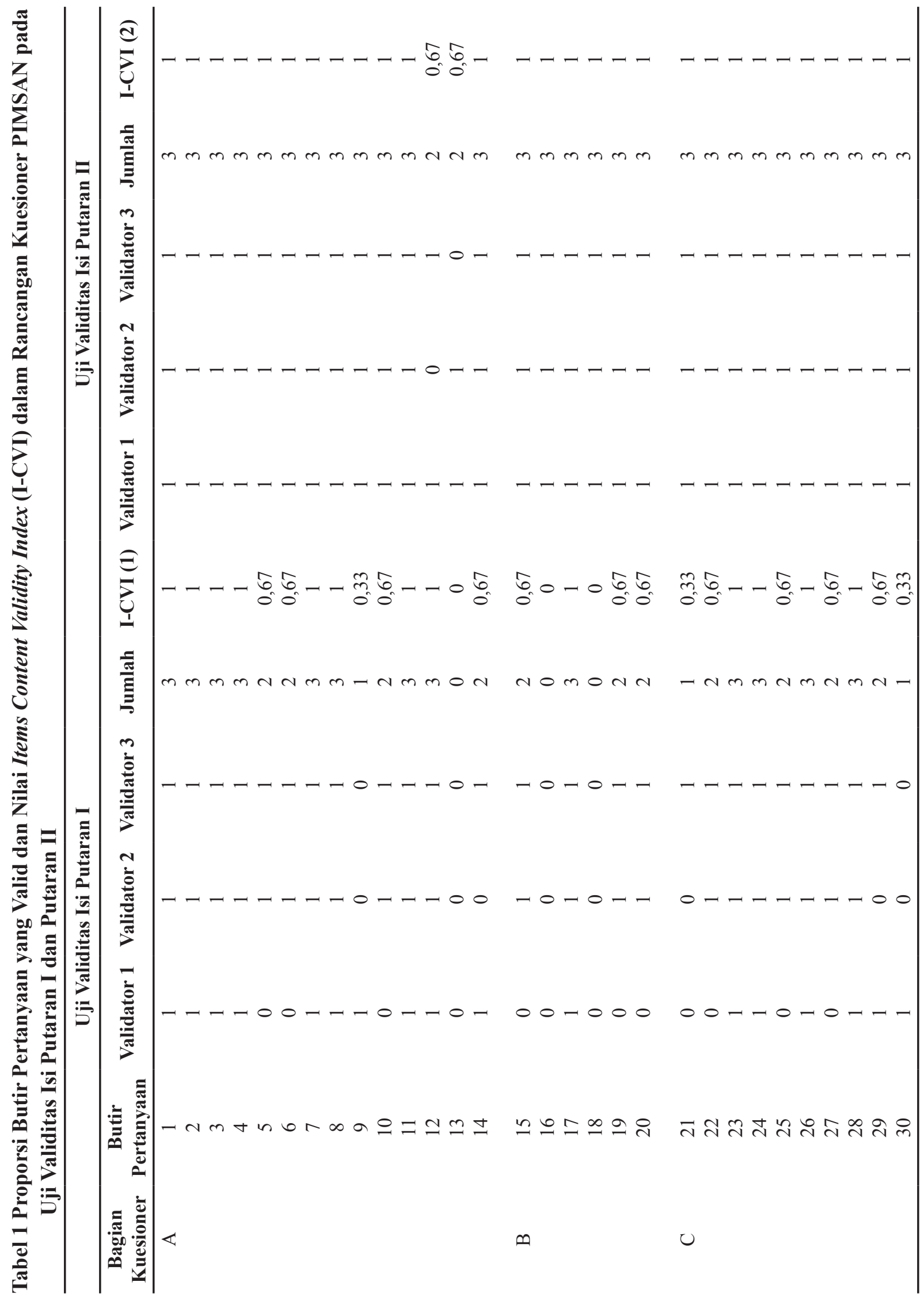




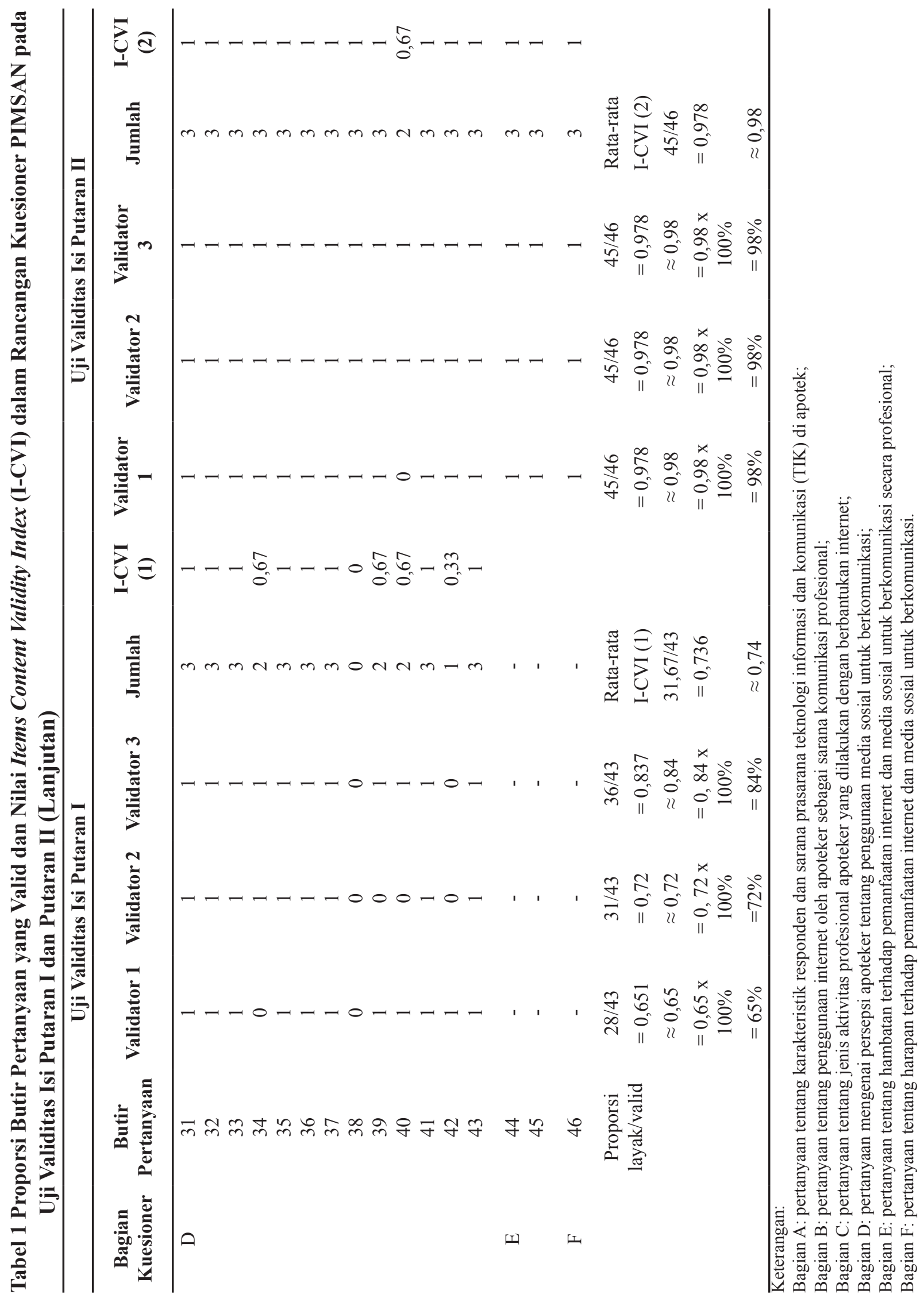


ketiga anggota panel ahli. Nilai I-CVI per butir pertanyaan dapat dilihat pada Tabel 1 . Pada putaran pertama, diperoleh nilai ratarata I-CVI sebesar 0,74. Pada putaran kedua, diperoleh nilai rata-rata I-CVI sebesar 0,98. Nilai I-CVI direkomendasikan di atas $0,78,{ }^{17}$ sehingga pada uji putaran kedua kuesioner dapat dinyatakan valid melalui pendekatan kuantitatif.

\section{Hasil uji pemahaman bahasa kuesioner PIMSAN}

Uji pemahaman bahasa dilakukan terhadap kuesioner PIMSAN yang telah dinyatakan valid dengan jumlah pertanyaan sebanyak 45 butir. Uji pemahaman bahasa dengan expert judgement pada putaran pertama memberikan hasil bahwa semua pilihan kata/bahasa yang digunakan untuk menyusun seluruh pertanyaan dalam kuesioner PIMSAN dinyatakan telah dapat mewakili makna yang dimaksudkan. Uji pemahaman bahasa kepada expert lolos dalam satu putaran.

Uji pemahaman bahasa kepada user di putaran pertama memberikan hasil masih terdapat pertanyaan yang belum dipahami oleh responden yakni di bagian $\mathrm{C}$ dan $\mathrm{D}$, seperti terlihat pada Tabel 2. Oleh karena itu, uji pemahaman bahasa dilanjutkan dengan putaran kedua, namun hanya kepada user yang memberikan penilaian "belum paham", yaitu user nomor 1 dan 2. Dengan demikian, uji pemahaman bahasa kepada user dinyatakan lolos setelah melalui dua putaran.

Hasil uji pemahaman bahasa memberikan beberapa perubahan yang disarankan baik oleh expert maupun user untuk mempermudah responden dalam memahami makna dari butirbutir pertanyaan yang diajukan. Misalnya, adanya penambahan subjudul pada tiap kolom pertanyaan yang disarankan oleh expert untuk mempermudah responden dalam pengisian kuesioner PIMSAN.

\section{Hasil uji reliabilitas kuesioner PIMSAN}

Uji reliabilitas dilakukan pada responden apoteker yang melakukan praktik pelayanan kefarmasian di dua kategori tempat praktik, yaitu apotek jejaring dan apotek nonjejaring (individu). Hasil uji reliabilitas dapat dilihat

Tabel 2 Proporsi Butir Pertanyaan yang Dipahami dalam Uji Pemahaman Bahasa Kepada User (Apoteker) pada Tiap Bagian Kuesioner PIMSAN

\begin{tabular}{|c|c|c|c|c|c|}
\hline \multirow{3}{*}{$\begin{array}{c}\text { Bagian Rancangan } \\
\text { Kuesioner } \\
\text { PIMSAN } \\
\text { (Nvalid=45) }\end{array}$} & \multicolumn{5}{|c|}{ Proporsi Butir Pertanyaan yang Dipahami } \\
\hline & \multicolumn{2}{|c|}{ User 1} & \multicolumn{2}{|c|}{ User 2} & \multirow{2}{*}{$\begin{array}{c}\text { User } \mathbf{3} \\
\text { Putaran I } \\
\text { (Tanpa Putaran II, Karena } \\
\text { Sudah } \mathbf{1 0 0 \%} \text { di Putaran I) }\end{array}$} \\
\hline & Putaran I & Putaran II & Putaran I & Putaran II & \\
\hline Bagian A $(n=13)$ & $100 \%$ & $100 \%$ & $100 \%$ & $100 \%$ & $100 \%$ \\
\hline Bagian $B(n=6)$ & $100 \%$ & $100 \%$ & $100 \%$ & $100 \%$ & $100 \%$ \\
\hline Bagian C (n=10) & $90 \%$ & $100 \%$ & $100 \%$ & $100 \%$ & $100 \%$ \\
\hline Bagian D $(n=13)$ & $100 \%$ & $100 \%$ & $84,61 \%$ & $100 \%$ & $100 \%$ \\
\hline Bagian $E(n=2)$ & $100 \%$ & $100 \%$ & $100 \%$ & $100 \%$ & $100 \%$ \\
\hline Bagian F $(n=1)$ & $100 \%$ & $100 \%$ & $100 \%$ & $100 \%$ & $100 \%$ \\
\hline
\end{tabular}

\section{Keterangan:}

Bagian A: pertanyaan tentang karakteristik responden dan sarana prasarana teknologi informasi dan komunikasi (TIK) di apotek; Bagian B: pertanyaan tentang penggunaan internet oleh apoteker sebagai sarana komunikasi profesional;

Bagian $\mathrm{C}$ : pertanyaan tentang jenis aktivitas profesional apoteker yang dilakukan dengan berbantukan internet; Bagian D: pertanyaan mengenai persepsi apoteker tentang penggunaan media sosial untuk berkomunikasi;

Bagian E: pertanyaan tentang hambatan terhadap pemanfaatan internet dan media sosial untuk berkomunikasi secara profesional; Bagian F: pertanyaan tentang harapan terhadap pemanfaatan internet dan media sosial untuk berkomunikasi. 
Tabel 3 Hasil Uji Reliabilitas Kuesioner PIMSAN di Tiap Kategori Tempat Praktik Responden Apoteker

\begin{tabular}{cc}
\hline Kategori Tempat Praktik Responden & Nilai Cronbach Alpha \\
\hline Apotek jejaring & 0,852 \\
Apotek nonjejaring & 0,852 \\
\hline
\end{tabular}

pada Tabel 3 .

Hasil uji reliabilitas yang didapatkan berupa nilai Cronbach Alpha. Nilai Cronbach Alpha yang baik berkisar antara 0,7 sampai 0,95. ${ }^{19}$ Masing-masing nilai Cronbach Alpha pada apotek jejaring sebesar 0,852 dan apotek nonjejaring (individu) sebesar 0,852. Kedua hasil tersebut menunjukkan bahwa nilai Cronbach Alpha $\geq 0,7$, sehingga kuesioner dapat dinyatakan reliabel (Tabel 4).

\section{Pembahasan}

Pengembangan instrumen dilakukan untuk menghasilkan kuesioner yang valid dan reliabel. Uji yang lazim dilakukan terhadap instrumen penelitian yang berupa kuesioner meliputi uji validitas isi, uji pemahaman bahasa, dan uji reliabilitas. ${ }^{18,20}$ Pengembangan kuesioner yang dinamakan "Penggunaan Internet dan Media Sosial untuk Pelayanan

Tabel 4 Nilai Cronbach Alpha Per Butir Pertanyaan dari Kuesioner PIMSAN pada Dua Kategori Tempat Praktik Responden (Apotek Jejaring dan Apotek Nonjejaring)

\begin{tabular}{ccc}
\hline \multirow{2}{*}{$\begin{array}{c}\text { Bagian D Kuesioner PIMSAN } \\
\text { N=13 }\end{array}$} & \multicolumn{2}{c}{ Kategori Tempat Praktik Responden } \\
\cline { 2 - 3 } & Apotek Jejaring & Apotek Nonjejaring \\
\hline D1 & 0,801 & 0,825 \\
D2 & 0,802 & 0,815 \\
D3 & 0,802 & 0,835 \\
D4 & 0,801 & 0,819 \\
D5 & 0,821 & 0,815 \\
D6 & 0,802 & 0,808 \\
D7 & 0,806 & 0,813 \\
D8 & 0,805 & 0,821 \\
D9 & 0,796 & 0,815 \\
D10 & 0,849 & 0,870 \\
D11 & 0,808 & 0,808 \\
D12 & 0,808 & 0,808 \\
D13 & 0,808 & 0,819 \\
\hline
\end{tabular}

\section{Keterangan:}

D1: Media sosial dapat digunakan secara efektif oleh apoteker untuk meningkatkan komunikasi dengan pasien;

D2: Media sosial perlu lebih banyak digunakan di tempat praktik apoteker sebagai sarana komunikasi dengan pasien;

D3: Media sosial perlu lebih banyak digunakan di tempat praktik apoteker sebagai sarana komunikasi dengan tenaga kesehatan lain;

D4: Media sosial tidak bermanfaat untuk melakukan komunikasi secara profesional antara apoteker dan pasien;

D5: Penggunaan media sosial untuk berkomunikasi dengan pasien membutuhkan waktu yang relatif lebih lama;

D6: Media sosial memiliki potensi untuk menjadi sarana komunikasi yang baik antara apoteker dengan pasien;

D7: Penggunaan media sosial dapat membantu upaya peningkatan kualitas hidup seorang pasien;

D8: Penggunaan media sosial dapat meningkatkan pengetahuan seorang pasien;

D9: Penggunaan media sosial dapat memfasilitasi penatalaksanaan terapi obat bagi pasien;

D10: Penggunaan media sosial memungkinkan pasien mendebat penguasaan pengetahuan seorang apoteker;

D11: Media sosial dapat meningkatkan hubungan profesional antara apoteker dengan pasien;

D12: Media sosial dapat mengubah cara interaksi pasien dengan apoteker;

D13: Penggunaan media sosial memungkinkan mengakses informasi kesehatan yang diragukan kebenarannya (misal: informasi hoaks). 
Kefarmasian (PIMSAN)" ini mengacu pada kuesioner yang telah digunakan pada sebuah penelitian berjudul "Community pharmacists, Internet and social media: An empirical investigation" yang dilakukan di Texas, USA oleh Shcherbakova dan Shepherd. Studi tersebut dilakukan pada tahun 2012 dan dipublikasikan pada jurnal Research in Social and Administrative Pharmacy (RSAP) pada tahun 2014. Kuesioner tersebut memuat total 25 pertanyaan, dengan 12 pertanyaan tentang persepsi yang berupa skala Likert. Responden pada penelitian Shcherbakova dan Shepherd ini adalah 284 apoteker yang berpraktik di komunitas. Hasil pengujian reliabilitas dengan nilai Cronbach Alpha terhadap pertanyaan dengan skala Likert pada studi Shcherbakova dan Shepherd ini sebesar $0,89 .{ }^{13}$

Pada penelitian ini dihasilkan kuesioner PIMSAN yang valid dan reliabel, sehingga dapat digunakan untuk menggambarkan fenomena penggunaan internet dan media sosial dalam pelayanan kefarmasian di apotek berdasarkan perspektif apoteker. Uji validitas isi dilakukan terhadap rancangan kuesioner PIMSAN (Ver01) dengan pendekatan kualitatif dan kuantitatif dengan metode professional judgement oleh panel ahli/validator, dan dinyatakan valid pada putaran kedua. Uji pemahaman dilakukan terhadap expert dan user. Uji pemahaman bahasa kepada expert dinyatakan lolos dalam satu putaran uji. Uji pemahaman bahasa kepada user dinyatakan lolos setelah dilakukan sebanyak dua kali putaran. Uji reliabilitas dinyatakan reliabel dengan nilai Cronbach Alpha $\geq 0,7$, yaitu 0,852 pada masing-masing responden apoteker di apotek jejaring dan nonjejaring.

Uji validitas isi (content validity) yang dilakukan melalui pendekatan kualitatif dan dengan metode professional judgement dapat memberikan keleluasaan untuk pengembangan dan perbaikan kualitas kuesioner yang diuji. Hal ini disebabkan melalui pendekatan kualitatif terbuka kesempatan untuk mendiskusikan dan mengklarifikasi hasil penilaian dengan expert panel untuk mencapai kesepakatan yang disebut professional agreement. Uji validitas isi dengan pendekatan kualitatif juga membuka kesempatan bagi expert panel sekaligus melakukan penilaian validitas muka (face validity), bahkan penilaian pemahaman bahasa pada kuesioner yang diuji. ${ }^{21}$ Pada uji validitas isi dengan pendekatan kuantitatif, nilai I-CVI digunakan untuk menggambarkan kesepakatan dari panel ahli terhadap kelayakan butir-butir pertanyaan dalam kuesioner yang diuji. Nilai I-CVI berkisar antara 0 sampai 1, dan dinyatakan dapat diterima jika $\geq 0,78 .{ }^{17,22}$

Hasil dari uji reliabilitas menunjukkan nilai Cronbach Alpha pada apotek jejaring sebesar 0,852 dan apotek nonjejaring sebesar 0,852 . Hasil ini hampir sama dengan nilai Cronbach Alpha kuesioner pada studi oleh Shcherbakova dan Shepherd yang digunakan sebagai acuan yaitu sebesar $0,89 .{ }^{13}$ Kuesioner dinyatakan reliabel dengan acuan batas bawah nilai Cronbach Alpha $\geq 0,7,{ }^{17,23}$ sehingga dapat dikatakan kuesioner PIMSAN yang diuji melalui penelitian ini reliabel. Sebuah alat ukur yang reliabel akan dapat memberikan hasil yang sama pada setiap pengukuran. ${ }^{17}$ Apabila nilai Cronbach Alpha yang dicapai di bawah batas bawah nilai, maka yang dapat dilakukan adalah menghitung nilai Cronbach Alpha tiap butir pertanyaan, dan kemudian menghilangkan butir-butir pertanyaan yang memiliki nilai Cronbach Alpha yang rendah. ${ }^{19}$ Namun demikian, hal tersebut mempunyai risiko apabila jumlah butir pertanyaan yang diuji terbatas, sehingga akan mengakibatkan semakin sedikitnya jumlah butir pertanyaan.

Beberapa faktor yang dapat memengaruhi pencapaian nilai Cronbach Alpha pada uji reliabilitas sebuah kuesioner di antaranya adalah banyaknya butir pertanyaan, waktu yang tersedia bagi responden untuk mengisi kuesioner yang diuji, keadaan diri responden saat pengisian, misalnya pengisian dilakukan 
sedang lelah atau kurang konsentrasi. Selain itu, terdapat pula faktor lain dari tim peneliti yang mungkin dapat memengaruhi jawaban responden. ${ }^{24}$ Faktor-faktor tersebut sebaiknya dapat diminimalisir terlebih dahulu sebelum dilakukan uji coba kepada responden.

\section{Simpulan}

Penelitian ini memaparkan langkah-langkah dalam pengembangan dan pengujian validitas dan reliabilitas kuesioner PIMSAN sebagai instrumen untuk mendeskripsikan persepsi apoteker terhadap penggunaan internet dan media sosial untuk pelayanan kefarmasian di apotek. Sebanyak 45 butir pertanyaan kuesioner PIMSAN dinyatakan valid dengan tercapainya professional agreement oleh tim validator dan nilai I-CVI sebesar 0,98. Kuesioner PIMSAN dinyatakan reliabel dengan nilai Cronbach Alpha pada pengujian di apotek jejaring dan nonjejaring masingmasing sebesar 0,852. Kuesioner PIMSAN juga telah dinyatakan lolos uji pemahaman bahasa. Oleh karena tu, kuesioner PIMSAN dapat digunakan sebagai instrumen untuk mengukur persepsi apoteker tentang penggunaan internet dan media sosial untuk pelayanan kefarmasian di apotek.

\section{Ucapan Terima Kasih}

Tim penulis mengucapkan terima kasih kepada para responden penelitian yang secara sukarela berpartisipasi dalam penelitian ini; kepada panel validator yang telah berkenan melakukan validasi isi kuesioner; kepada Enade Perdana Istyastono, PhD., Apt. dan Dr. Yosef Wijoyo, Apt. yang telah memberikan masukan berharga pada bagian proposal penelitian. Terima kasih untuk dukungan pendanaan dari Kemenristek DIKTI melalui Hibah Penelitian Tesis Magister tahun 2019 (Nomor 029/Penel./LPPM_USD/IV/2019). Kuesioner lengkap dapat diperoleh dari penulis korespondensi melalui email.

\section{Pendanaan}

Penelitian pendahuluan ini merupakan bagian dari penelitian utama diselenggarakan dengan dana dari Kemenristek DIKTI melalui Hibah Penelitian Tesis Magister tahun 2019 (Nomor 029/Penel./LPPM_USD/IV/2019).

\section{Konflik Kepentingan}

Seluruh penulis menyatakan tidak terdapat potensi konflik kepentingan dengan penelitian, kepenulisan (authorship), dan atau publikasi artikel ini.

\section{Daftar Pustaka}

1. Sucahyo YG, Basaruddin C. Sistem kesehatan nasional berbasis IT (e-Health) di Indonesia [diunduh 11 April 2019]. Tersedia dari: https://scele.ui.ac.id/berkas _kolaborasi/konten/mpktb_2015gasal/07 5.pdf

2. Jadhav S, Nikam K, Gandhi A, Shinde N, Salunuke K. Applications of computer science in pharmacy: An overview. Natl J Physiol Pharm Pharmacol. 2012;2(1):1-9.

3. Mariz S. Medicines and the internet. J Malta Coll Pharm Pract. 2010;21(16):89.

4. WHO. e-Health, 2018 [diunduh 11 April 2019]. Tersedia dari: https://www.who.int/ ehealth/about/en/

5. Norman CD, Skinner HA. eHEALS: The eHealth literacy scale. J Med Internet Res. 2006;8(4):e27. doi: 10.2196/jmir.8.4.e27

6. Mitsutake S, Shibata A, Ishii K, Oka K. Associations of eHealth literacy with health behavior among adult internet users. J Med Internet Res. 2016;18(7):e192. doi: 10.2196/jmir.5413

7. Asosiasi Penyelenggara Jasa Internet. Penetrasi \& perilaku pengguna internet 
Indonesia survey 2017 [diunduh 11 April 2019]. Tersedia dari: https://apjii.or.id/ survei

8. Cahyono L, Winarno W, Nugroho $\mathrm{H}$. Virtualisasi medis: Analisis kecenderungan masyarakat mencari informasi kesehatan di internet. Prosiding Seminar Nasional Teknologi Informasi dan Multimedia; 6-8 Februari 2015; Yogyakarta, Indonesia. Indonesia: STMIK AMIKOM; 2015.

9. Mazer M, Deroos F, Shofer F, Hollander J, McCusker C, Peacock N, et al. Medications from the web: Use of online pharmacies by emergency department patients. J Emerg Med. 2012;42(2):227-32. doi: 10. 1016/j.jemermed.2010.05.035.

10. Abanmy N. The extent of use of online pharmacies in Saudi Arabia. Saudi Pharm J. 2017;25(6):891-9. doi: 10.1016/j.jsps. 2017.02.001.

11. Chaturvedi A, Singh UK, Kumar A. Online pharmacy: An e-strategy for medication. Int J Pharm Front Res. 2011; 1(1):146-58.

12. Ong SW, Hassali MA, Saleem F. Community pharmacists' perceptions towards online health information in Kuala Lumpur, Malaysia. Pharm Pract. 2018;16 (2):1166. doi: 10.18549/PharmPract.2018.0 2.1166 .

13. Shcherbakova N, Shepherd M. Community pharmacists, internet and social media: An empirical investigation. Res Soc Adm Pharm. 2014;10(6):e75-85. doi: 10.1016/j. sapharm.2013.11.007.

14. Chen YY, Li CM, Liang JC, Tsai CC. Health information obtained from the internet and changes in medical decision making: Questionnaire development and cross-sectional survey. J Med Internet Res. 2018;20(2):e47. doi: 10.2196/jmir.9370.

15. Jones R. Development of a questionnaire and cross-sectional survey of patient
eHealth readiness and eHealth inequalities. J Med Internet Res. 2013;2(2):e9. doi: 10. 2196/med20.2559

16. Seto S. Manajemen farmasi 1: Dasar-dasar akuntansi untuk apotek, PBF dan industri farmasi edisi 2. Surabaya: Airlangga University Press (AUP); 2017.

17. Bolarinwa OA. Principles and methods of validity and reliability testing of questionnaires used in social and health science researches. Niger Postgrad Med J. 2015;22(4):195-201. doi: 10.4103/11171936.173959.

18. Notoatmodjo S. Metodologi penelitian kesehatan. Jakarta: PT Asdi Mahasatya; 2010.

19. Tavakol M, Dennick R. Making sense of Cronbach's Alpha. Int J Med Educ. 2011; 2:53-5. doi: 10.5116/ijme.4dfb.8dfd

20. Sugiyono. Metode penelitian kuantitatif kualitatif dan R\&D. Bandung: Alfabeta; 2014.

21. Zamanzadeh V, Ghahramanian A, Rassouli M, Abbaszadeh A, Alavi-Majd H, Nikanfar A-R. Design and implementation content validity study: Development of an instrument for measuring Patient-Centered Communication. J Caring Sci. 2015;4(2): 165-78. doi: 10.15171/jcs.2015.017.

22. Polit DF, Beck CT, Owen SV. Is the CVI an acceptable indicator of content validity? Res Nurs Health. 2007;30(4):121. doi: 10.1002/nur.20199

23. Taber KS. The use of Cronbach's Alpha when developing and reporting research instruments in science education. Res Sci Educ. 2018;48(6):1273-96. doi: 10.1007/ s11165-016-9602-2

24. Wongpakaran N, Wongpakaran T. Reliability analysis: Its application in clinical practice. In: Press Ic, editor. Vaccines: Benefits and Risks; 2012.

(C) 2019 Heryanto et al. The full terms of this license incorporate the Creative Common Attribution-Non Commercial License (https://creative commons.org/licenses/by-nc/4.0/). By accessing the work you hereby accept the terms. Non-commercial use of the work are permitted without any further permission, provided the work is properly attributed. 